\title{
THE ANALYSIS OF LITERAL TRANSLATION METHOD ENGLISH INTO INDONESIAN IN SHORT STORY ENTITLED "MERCURY AND THE CARPENTER"
}

\author{
Effendi Zaenal Mutaqin', Wati Sulistyawati ${ }^{2}$ \\ ${ }^{1}$ IKIP Siliwangi \\ ${ }^{2}$ IKIP Siliwangi \\ ${ }^{1}$ nurenzm@gmail.com, ${ }^{2}$ Watisulistyawati08@gmail.com
}

\begin{abstract}
The purpose of this research is to know whether there are literal translation method used in the short story entitled Mercury and the Carpenter or not. This study used qualitativee descriptive research. The source of this research used document of short story entitled "Mercury and the Carpenter" either in English or Indonesian written by Sergius Lesky. As for the limitation, this research is only analyzing about method of literal translation. In collecting data, the researhcer read the short story both in English and Indonesian, then analyzed the method of literal transation. In analyzing data, the researcher used the method of document analyzing with taxonomy analysis, in the other word, the researcher classified the data into the method of literal translation. Based on the data analysis "Mercury and the Carpenter", the researcher had founded 8 data of Literal translation method.
\end{abstract}

Keywords: Translation, Method, Short Story

\section{INTRODUCTION}

In the world there are approximately 912 languages, this amount has not been accurate, because in year to year there are decreasing or increasing of languages. It indicates that many languages in the world. Because of it, to communicate with one another or various countries with different language either directly or not, we need a translation. The translation is to transfer message of one language to another language without reducing the meaning or message. Translation as the replacement of textual material in Source Language (SL) by equivalent textual material in Target Language (TL) (Catford in Djuharie, 2013:11).

However, for a student who is studying English or an English teacher the translation is very difficult, especially when we want to know about methods of translation. Methods of translation are the ways in translating from a language to another language. Sometimes, a teacher teaches students about English short story at school. The teacher will translate the short story into Bahasa Indonesia, if the teacher knows the methods of translation, so the result of translation will be more perfect.

In the other hand, sometimes if we read translated book or short story, we could not understood what we have read. It maybe the translation method used was mistake so that the messege of source language could not be transferred into target language ferpectly.

Short story in Bahasa Indonesia called Cerpen or Cerita Pendek. According to Notosusanto (in Novrizal, 2017)"Cerita pendek yaitu sebuah cerita yang panjang ceritanya berkisar 5000 kata atau perkiraan hanya 17 halaman kuarto dengan spasi rangkap serta terpusat pada dirinya 
sendiri." It means that short story is a story has approximately 5.000 words or 17 pages with double space.

As for the short story was analyzed by author entitled "Mercury and the Carpenter". This story tells about the poor carpenter who lost his axe in the river. Then, Mercury helped him to search the axe. Mercury found and gave him gold and a silver axe. But carpenter did not take them. Then, because he is the honest man, finally Mercury gave him gold axe as prize.

The purpose of this study is to know whether there are literal translation method used in short story entitled "Mercury and the Carpenter" or not. For the effectiveness of this research, the author limited this research. As for the limitation, this research was only analyzing about method of translation in the short story entitled "Mercury and the Carpenter." This short story written by Sergius Lesky with website is http://www.bahasainggrisku.com/2018/02/ceritapendek-bahasa-inggris-dan-terjemahannya .html. This short story was not best seller category, but this short story was interested to be analyzed. In the other hand, it told us should be honest people. This study was focused on Literal translation method. Thus, the researcher analyzed whether there are literal translation method used in this short story or not.

\section{Translation}

According to Nida and Taber (1969:12), "Reproducing in the receptor language the closest natural equivalent of the source language messege, first in terms of meaning and secondly in terms of style. According to Newmark (1988:05) translation is, "rendering themeaning of a text into another language in the way that the author intended the text". Apart from transferring a message, translation transfers form of the language either literature or scientific works, also evaluates the content and the translation. Therefore, based on the definition above, translation is a process of message transferring from SL with natural equivalent into TL naturally.

\section{Method of Translation}

In the method of translation, we know that there are two kind of translation methods. Fist, the method which is emphasized on Source Language (SL) such as word-for-word translation, literal translation, faithful translation, and semantic translation. Second, the method is emphasized on Target Language (TL) such as adaptation, free translation, idiomatic translation, and communicative translation (Newmark, 1988:45-47). Newmark putit in the form of a flattened V diagram:

\section{SL emphasis}

Word-for-word

Literal translation

Faithful translation

$\underline{\text { Semantic translation }}$

\section{TL emphasis}

Adaptation

Free translation

$\underline{\text { Idiomatic translation }}$

Communicative translation

Based on $\mathrm{V}$ diagram above, in translating we should use TL emphasis (adaptation, free translation, idiomatic translation, and communicative translation), these translation methods emphasize on target language so that the reader can be more understand in reading the result our translation. Based on the statement, the researcher tried to analyze Literal translation method. In liteural translation, the structure of grammar converted to their nearest TL 
equivalents but the lexical words are again translated singly, without considering the context. It is used in pre-translation process to show the problems must be solved.

SL : His hearth is in the right place.

TL : Hatinya berada di tempat yang benar.

Taken from (Newmark, 1988:45-47)

\section{Short Story}

Short story is usually a story tells about the real life like legend, in Bahasa Indonesia, it is called as Cerpen or Cerita Pendek. According to Sadewo (2012), "Cerita pendek atau sering disingkat sebagai cerpen adalah suatu bentuk prosa naratif fiktif. Cerita pendek cenderung padat dan langsung pada tujuannya dibandingkan karya-karya fiksi yang lebih panjang, seperti novella (dalam pengertian modern) dannovel. It means that short story is a kind of fictive narrative prose, this story is more short than novel. Then Notosusanto (Novrizal, 2017) said that, "Cerita pendek yaitu sebuah cerita yang panjang ceritanya berkisar 5000 kata atau perkiraan hanya 17 halaman kuarto dengan spasi rangkap serta terpusat pada dirinya sendiri." It means that short story is a story has approximately 5.000 words or 17 pages with double space. As for the kind of short story based on the number of the word, short story is a one of literature work that is fiction prose having approximately $750-10.000$ words. Based on the amount of word, there are three types of short story such as Mini Short Story (Flash), this type has approximately 750 -1.000 words. Ideal Short Story, this type has around 3.000 - 4.000 words. Long Short Story, this type has 10.000 words (Sadewo, 2012).

\section{METHOD}

This study used qualitative descriptive research. Qualitative is a kind of research needs data like written and verbal data or an action can be observed, while, descriptive is a research method that gives an explanation about thing clearly, without measure to the research object (Jauhari, 2010:34-35). Consequently, the author used qualitative research kind using written data (short story). Then, the author used method of descriptive to explain and analyze data intensively. The problems analyzed in this study was about method of translation in the short story of Mercury and the Carpenter. Source of research data likes paper. Paper is data source which present letters (Cahyaningrum, 2013:35). It likes document or short story entitled Mercury and the Carpenter short story by Sergius Lesky with website is http://www.bahasainggrisku.com /2018/02/ceritapendek-bahasa-inggris-danterjemahannya. html. As for, the technique of data collection. Firstly, reading the short story will be analyzed both source language (SL) and target language (TL). Secondly, analyzing the method of translation in the TL. this interview to ask whether the method will be analyzed is correct or not. Finally, data has been collected, given a code based on SL, TL, and order number, for example:

Code : SL/001

Comment : SL : Source Language

001 : order number of data

This research used documentation study data of Mercury and the Carpenter short story. It is a qualitative data, so this analysis must has qualitative requirement. According to Moloeng (in Jauhari, 2010:36), "Pekerjaan analisis data dalam hal ini ialah mengatur, mengurutkan, mengelompokkan, memberi kode, dan mengkategorikannya."It means that analyzing data is a method to organize, order, give a code, and classify. In analyzing data, there is a method called taxonomy analysis, this stage is a method to classify data into various method of translation, the example as following: 
Table 1. Classifying of Free Translation Method

\begin{tabular}{|l|l|l|}
\hline \multirow{2}{*}{$\begin{array}{l}\text { Data } \\
\text { Number }\end{array}$} & \multicolumn{2}{|c|}{ Short Story per Sentence } \\
\cline { 2 - 3 } 001 & $\begin{array}{l}\text { Look, little guy, you-all } \\
\text { shouldn't be doing that. } \\
\text { The flowers in the garden. }\end{array}$ & $\begin{array}{l}\text { Lihat, kecil anak, kamu semua harus } \\
\text { tidak melakukan ini. }\end{array}$ \\
& Bunga-bunga yangtumbuh di kebun \\
\hline
\end{tabular}

\section{RESULTS AND DISCUSSION}

\section{Results}

Based on the data analysis about "Mercury and the Carpenter", the researcher found 8 data of Literal translation method. The data as follow.

\begin{tabular}{lll}
\hline \multirow{2}{*}{ Data } & \multicolumn{1}{c}{ Short Story per Sentence } \\
\cline { 2 - 3 } $\mathbf{0 0 1}$ & \multicolumn{1}{c}{ SL } & \multicolumn{1}{c}{ TL } \\
& $\begin{array}{l}\text { Once upon a time there was a } \\
\text { poor carpenter who lived with his } \\
\text { family near a deep river. }\end{array}$ & $\begin{array}{l}\text { Sekali peristiwa ada seorang tukang } \\
\text { kayu miskin yang hidup bersama } \\
\text { keluarganya di dekat sungai yang } \\
\text { dalam. }\end{array}$ \\
\hline $\mathbf{0 0 2}$ & $\begin{array}{l}\text {...when suddenly his axe fell into } \\
\text { the river. }\end{array}$ & $\begin{array}{l}\text {..ketika tiba-tiba kapaknya jatuh ke } \\
\text { dalam sungai. }\end{array}$ \\
\hline $\mathbf{0 0 3}$ & I've lost my axe in the river. & $\begin{array}{l}\text { Aku telah kehilangan kapakku ke } \\
\text { dalam sungai. }\end{array}$ \\
\hline $\mathbf{0 0 4}$ & $\begin{array}{l}\text { I've just dropped my axe into the } \\
\text { river. }\end{array}$ & $\begin{array}{l}\text { Aku baru saja menjatuhkan kapakku } \\
\text { ke dalam sungai }\end{array}$ \\
\hline $\mathbf{0 0 5}$ & I'll be glad to help you. & $\begin{array}{l}\text { Aku sangat senang untuk } \\
\text { membantumu. }\end{array}$ \\
\hline $\mathbf{0 0 6}$ & He came up with a beautiful axe & $\begin{array}{l}\text { Ia datang dengan sebuah kapak yang } \\
\text { indah }\end{array}$ \\
\hline $\mathbf{0 0 7}$ & $\begin{array}{l}\text { He thanked Mercury and went } \\
\text { home. }\end{array}$ & $\begin{array}{l}\text { Ia berterima kasih pada Merkuri dan } \\
\text { kembali ke rumah. }\end{array}$ \\
\hline $\mathbf{0 0 8}$ & one of the neighbours was very \\
greedy man. & $\begin{array}{l}\text { Salah satu dari tetangganya adalah } \\
\text { orang yang sangat serakah. }\end{array}$ \\
\hline
\end{tabular}




\section{Discussion}

The researcher had founded 8 data of Literal translation. For examples are from data number 004 and 006 as follow

SL : I've just dropped my axe into the river.

TL : Aku baru saja menjatuhkan kapakku ke dalam sungai.

Based on data number 004, we can see that this translation used literal translation method, the translator had translated "dropped my axe into the river" to be "menjatuhkan kapakku ke dalam sungai". This translation was correct literally, but based on the context it was incorrect. It should be translated to be "tenggelam ke sungai". Because in context, the axe dropped was not intended.

Then, for the example of number 006.

SL : He came up with a beautiful axe.

TL : Ia datang dengan sebuah kapak yang indah.

This data used literal translation, the translator translated SL to be "I $a$ datang dengan sebuah kapak yang indah". Contextly, it should be translated to be "ia muncul membawa kapak yang indah”.

\section{CONCLUSION}

The researcher had done analysis about literal translation method on the translation of short story entitled "Merury and the Carpenter". Based on the data analysis about "Mercury and the Carpenter", the researcher had founded 8 data of Literal translation method. The translation as whole were correct literally, but they were incorrect contextly. Based on the analysis, in professional translation, literal translation is not recommended, because it can make difference interpretation.

\section{ACKNOWLEDGMENTS}

Alhamdulillahirabbil'alamin, praise and thank you to Allah SWT, the Most Gracious, and Most Merciful. Praise God for the blessings given to the authors so that can complete this article.

\section{REFERENCES}

Cahyaningrum, I. O. (2013). Analisis Teknik dan Kualitas Terjemahan Kalimat Tanya pada Subtitle Film Sherlock Holmes. Surakarta.

Djuharie, O. S. (2013). Teknik dan Panduan Menterjemahkan Bahasa inggris-Bahasa Indonesia. Bandung: Yrama Widya.

Jauhari, H. (2010). Pedoman Penulisan Karya Ilmiah. Bandung: CV. Pustaka Setia.

Newmark, P. (1988). A Texbook of Translation. UK: Prentice HaH International vUIO Ltd.

Nida, A. E. and C. R. T. (1969). The Theory and Practice of Translation. Retrieved from http://novrizaltv.blogspot.co.id/ 2017/05/cerpen-pengertian-ciri-ciri-jenis-dan.html

Novrizal. (2017). Cerpen Pegerian Ciri-ciri Jenis. Retrieved May 12, 2019, from http://novrizaltv.blogspot.co.id/ 2017/05/cerpen-pengertian-ciri-ciri-jenis-dan.html

Sadewo. (2012). Makalah Cerpen. Retrieved May 12, 2019, from http://kokosadewo11bhs08.blogspot.co.id/2012/11/makalah-cerpen.html 